\title{
Estrogen receptor beta inhibits transcriptional activity of hypoxia inducible factor-1 through the downregulation of arylhydrocarbon receptor nuclear translocator
}

Wonchung Lim', Yeomyung Park', Jungyoon Cho', Choa Park', Joonwoo Park', Young-Kwon Park², Hyunsung Park ${ }^{2}$ and YoungJoo Lee ${ }^{1 *}$

\begin{abstract}
Introduction: Estrogen receptor (ER) $\beta$ is predicted to play an important role in prevention of breast cancer development and metastasis. We have shown previously that ER $\beta$ inhibits hypoxia inducible factor (HIF)- $1 \alpha$ mediated transcription, but the mechanism by which ER $\beta$ works to exert this effect is not understood.

Methods: Vascular endothelial growth factor (VEGF) was measured in conditioned medium by enzyme-linked immunosorbent assays. Reverse transcription polymerase chain reaction (RT-PCR), Western blotting,

immunoprecipitation, luciferase assays and chromatin immunoprecipitation (ChIP) assays were used to ascertain the implication of ERß on HIF-1 function.

Results: In this study, we found that the inhibition of HIF-1 activity by ER $\beta$ expression was correlated with ER $\beta$ 's ability to degrade aryl hydrocarbon receptor nuclear translocator (ARNT) via ubiquitination processes leading to the reduction of active HIF-1 $\alpha$ /ARNT complexes. HIF-1 repression by ER $\beta$ was rescued by overexpression of ARNT as examined by hypoxia-responsive element (HRE)-driven luciferase assays. We show further that ER $\beta$ attenuated the hypoxic induction of VEGF mRNA by directly decreasing HIF-1 $\alpha$ binding to the VEGF gene promoter.
\end{abstract}

Conclusions: These results show that ER $\beta$ suppresses HIF-1 $\alpha$-mediated transcription via ARNT down-regulation, which may account for the tumour suppressive function of ERB.

\section{Introduction}

Estrogen plays a key role in the pathogenesis of breast cancer [1]. The cellular response to estrogen is mediated by two estrogen receptor (ER) isoforms, ER $\alpha$ and ER $\beta$ [2]. ER is the primary target for chemoprevention and endocrine therapy in breast cancer and provides prognostic and predictive information about tumour response to endocrine treatment [3]. A series of reports strongly indicated that estrogens, via ER $\alpha$, stimulate proliferation and inhibit apoptosis [4,5], whereas ER $\beta$ opposes the proliferative effect of ER $\alpha$ in vitro [6,7]. The alteration of the intracellular ER $\alpha / E R \beta$ ratio affects

\footnotetext{
* Correspondence: yjlee@sejong.ac.kr

'Department of Bioscience and Biotechnology, College of Life Science, Institute of Biotechnology, Sejong University, Kwangjingu, Kunjadong, Seoul 143-747, Korea

Full list of author information is available at the end of the article
}

the estrogen-induced cellular response [8]. In addition to its role in modulating ER $\alpha$-mediated regulation, ER $\beta$ also has distinct functions. Expression of ER $\beta$ significantly reduced cancer cell proliferation and tumour growth in severe combined immunodeficient mice [9]. ER $\beta$ inhibited proliferation of colon cancer cells [10]. It was suggested that the loss of ER $\beta$ expression may be one of the events leading to cancer development [11].

Hypoxia regulates a set of cellular functions, such as increased angiogenesis, energy metabolism, and erythropoiesis [12]. The adaptive response to hypoxia is controlled primarily by hypoxia-inducible factors (HIFs), which are master regulators of hypoxic gene expression and oxygen homeostasis [13-15]. HIF-1 plays a role in the physiologic regulation of a number of genes, such as vascular endothelial growth factor (VEGF), erythropoietin, 
and glucose transporter- 1 expression in various tissues [16-18]. HIF-1 functions as a heterodimer, comprised of an oxygen-labile $\alpha$-subunit and a stable $\beta$-subunit, also referred to as aryl hydrocarbon receptor nuclear translocator (ARNT) [15]. The HIF-1 $\alpha$ subunit is degraded through a proteasome pathway under normoxia, whereas ARNT is constitutively expressed and located in the nucleus. At low oxygen levels, stabilized HIF-1 $\alpha$ translocates to the nucleus, where the functionally active HIF-1 $\alpha$ /ARNT complex activates the transcription of target genes after binding to cognate hypoxia-responsive elements (HRE) [19]. ARNT expression levels constitute important determinants of hypoxia responsiveness [20]. In addition to its role in the hypoxic pathway, ARNT interacts and functions as a potent coactivator of both ER $\alpha$ - and ER $\beta$-dependent transcription [21]. The C-terminal domain of ARNT is essential for the transcriptional enhancement of ER activity [2]. ARNT is also required for aryl hydrocarbon receptor (AhR) function in 2,3,7,8-tetrachlorodibenzo-pdioxin signalling [22]. Sequestering ARNT, by using a truncated AhR, blocks the hypoxia and ER signalling pathways [23]. The regulation of ARNT is implicated to have a significant impact on hypoxia and estrogen signalling pathways.

We recently reported that ER $\beta$ inhibits HIF- $1 \alpha$ mediated transcription [24]. However, the mechanism of ER $\beta$ on hypoxia-induced transcription is unknown. In this study, we show that ER $\beta$ significantly decreases the hypoxic induction of VEGF mRNA by inhibiting HIF-1mediated transcription via ARNT downregulation providing mechanistic evidence for the anti-angiogenic effect of ER $\beta$.

\section{Materials and methods \\ Materials}

17- $\beta$-estradiol (E2) and 2,3,7,8-tetrachlorodibenzo-pdioxin (TCDD) (Supelco, Bellefonte, PA, USA) were purchased from Sigma (St. Louis, MO, USA) and dissolved in $100 \%$ ethanol. ICI182,780 (ICI) was obtained from ZENECA Pharmaceuticals (Tocris, UK). MG132 (Sigma) was dissolved in dimethyl sulfoxide. All of the compounds were added to the medium such that the total solvent concentration was never higher than $0.1 \%$. An untreated group served as a control. Anti-ER $\beta$ was purchased from GeneTex (GTX110607, Irvine, CA, USA). Anti-ARNT and anti-HIF-1 $\alpha$ were obtained from BD Biosciences (San Jose, CA, USA). Anti- $\beta$-actin and anti-ubiquitin were purchased from Sigma.

\section{Cell culture and hypoxic conditions}

Hep3B and Human embryonic kidney 293 (HEK293) cells were maintained in phenol red-free Dulbecco's modified Eagle medium (DMEM) supplemented with $10 \%$ fetal bovine serum (FBS). MCF-7 and PC3 cells were maintained in phenol red-free RPMI 1640 medium supplemented with $10 \% \mathrm{FBS}$. Cells were grown at $37^{\circ} \mathrm{C}$ in a humidified atmosphere of $95 \%$ air $/ 5 \% \mathrm{CO}_{2}$ and fed every two to three days. Before treatment, the cells were washed with phosphate-buffered saline and cultured in DMEM/5\% charcoal-dextran stripped FBS (CD-FBS) for two days to eliminate any estrogenic source before treatment. All treatments were done with DMEM/5\% CDFBS. We used $10 \mathrm{nM}$ E2, unless otherwise noted. For the hypoxic condition, cells were incubated at a $\mathrm{CO}_{2}$ level of $5 \%$ with $1 \% \mathrm{O}_{2}$ balanced with $\mathrm{N}_{2}$ using a hypoxic chamber (Forma, Costa Mesa, CA, USA).

\section{Plasmids}

The hER $\beta$ expression vector was kindly provided by Dr. Mesut Muyan (University of Rochester Medical School, USA). The HRE-Luc reporter plasmid contains four copies of the erythropoietin HRE, the SV40 promoter, and the luciferase gene. Green fluorescent protein (GFP) tagged HIF-1 $\alpha$ (GFP-HIF-1 $\alpha$ ) vector was kindly provided by Dr. Kyu-Won Kim (Seoul National University, Korea). The plasmid His-tagged ubiquitin (His-Ub) was constructed by inserting a single copy of the Ub gene (76 amino acids) into pcDNA3.1/HisC (Invitrogen, Carlsbad, CA, USA).

\section{Transient transfection and luciferase assay}

HEK293 and MCF-7 were transiently transfected with plasmids by using the polyethylenimine (PEI; Polysciences, Warrington, PA, USA). Luciferase activity was determined 24 or $48 \mathrm{~h}$ after treatment with an AutoLumat LB953 luminometer using the luciferase assay system (Promega Corp., Madison, WI, USA) and expressed as relative light units. The means and standard deviations (SD) of three replicates are shown for the representative experiments. All transfection experiments were repeated three or more times with similar results. PC3 cells were transfected transiently with Lipofectamine 2000 (Invitrogen) and On-Target Plus SMARTpool siRNAs (Dharmacon, Lafayette, CO, USA) for ER $\beta$ Nontargeting pools were used as negative controls.

Reverse transcription (RT)-Polymerase chain reation (PCR) Total RNA was extracted using Trizol reagent (Invitrogen) according to the manufacturer's instruction. RNA pellets were dissolved in diethylpyrocarbonate-treated water. To synthesize first strand cDNA, $3 \mu \mathrm{g}$ total RNA was incubated at $70^{\circ} \mathrm{C}$ for five minutes with $0.5 \mu \mathrm{g}$ of random hexamer and deionized water (up to $11 \mu \mathrm{l}$ ). The reverse transcription reaction was performed using 40 units of M-ML reverse transcriptase (Promega) in $5 \times$ reaction buffer $(250 \mathrm{mmol} / \mathrm{l}$ Tris- $\mathrm{HCl}$; $\mathrm{pH} 8.3,375 \mathrm{mM}$ $\mathrm{KCl}, 15 \mathrm{mM} \mathrm{MgCl}, 50 \mathrm{mM}$ DTT), RNase inhibitor at $1 \mathrm{unit} / \mu \mathrm{l}$, and $1 \mathrm{mM} \mathrm{dNTP}$ mixtures at $37^{\circ} \mathrm{C}$ for 
60 minutes. The resulting cDNA was added to the PCR reaction mixture containing $10 \times \mathrm{PCR}$ buffer $(100 \mathrm{mM}$ Tris- $\mathrm{HCl}, \mathrm{pH} 8.3,500 \mathrm{mM} \mathrm{KCl}, 15 \mathrm{mM} \mathrm{MgCl}_{2}$ ), 25 units of rTaq polymerase (TakaRa, Shiga, Japan), $4 \mu \mathrm{l}$ of $2.5 \mathrm{mM}$ dNTP mixtures, and 10 pmol of primers each. The resulting cDNA samples were amplified using Mastercycler gradient (Eppendorf, Hauppauge, NY, USA). The primers used were: VEGF sense primer, 5'ATGAACTTTCTGCTCTCTGG -3'; anti-sense primer, 5'TCATCTCTCCTATGTGCTGGC-3'; $\beta$-actin sense primer, 5'-CCTGACCCTGAAGTACCCCA-3'; anti-sense primer, 5'-CGTCATGCAGCTCATAGCTC-3'. Quantitative real-time PCR (qPCR) was used to detect cytochrome 4450 (CYP) 1A1. qPCR was performed using $\mathrm{iQ}^{\mathrm{TM}}$ SYBR Green Supermix (Bio-Rad, Hercules, CA, USA). The primers used were: $\beta$-actin sense primer, 5'- CAAATGCTTCTAGGCGGACTATG-3'; anti-sense primer, 5'- TGCGCAAGTTAGGTTTTGTCA -3'; CYP 1A1 sense primer, 5'- TAGACACTGATCTGGCTGCA-3'; anti-sense primer, 5'- GGGAAGGCTCCATCAGCATC-3'; ER $\beta$ sense primer, 5'- GTCAGGCATGCGAGTAACAA-3'; anti-sense primer, 5'-GGGAGCCCTCTTTGCTTTTA-3'. A final volume was $25 \mu \mathrm{l}$, and an iCycler iQ Real-time PCR Detection System (Bio-Rad) was used for qPCR. The amplification data were analyzed by $\mathrm{iQ}^{\mathrm{TM}} 5$ optical system software version 2.1 and calculated using the $\Delta \Delta C_{\mathrm{T}}$ method. The $\Delta \Delta \mathrm{C}_{\mathrm{T}}$ method was used to calculate relative mRNA expression. The relative target gene expression was calculated using $2^{-\Delta \Delta C T}$, where $\Delta C_{\mathrm{T}}=\operatorname{target} C_{\mathrm{T}}-$ control $\mathrm{C}_{\mathrm{T}}$, $\Delta \Delta \mathrm{C}_{\mathrm{T}}=\Delta \mathrm{C}_{\mathrm{T}}$ target $-\Delta \mathrm{C}_{\mathrm{T}}$ calibrator.

\section{VEGF ELISA}

After hypoxic exposure, culture medium was removed and stored at $-80^{\circ} \mathrm{C}$ until assayed. VEGF concentrations were determined using an ELISA kit (R\&D Systems, Minneapolis, MN, USA) according to the manufacturer's instructions. Samples from two different experiments were analyzed in triplicate.

\section{Western blot analysis}

Protein extracts were isolated in lysis buffer $(150 \mathrm{mM}$ $\mathrm{NaCl}, 50 \mathrm{mM}$ Tris- $\mathrm{HCl}$ (pH 8.0), 5 mM EDTA, 1\% Nonidet P-40, 0.5\% deoxycholate, 1\% SDS) with protease inhibitor cocktail (Sigma) on ice for $1 \mathrm{~h}$ and then centrifuged for 20 minutes at $13,000 \times \mathrm{g}$. Supernatant was collected and protein concentrations were measured using the Bradford method (Bio-Rad). Proteins were dissolved in sample buffer and boiled for five minutes prior to loading onto a polyacrylamide gel. After SDS-PAGE, proteins were transferred to a polyvinylidene difluoride membrane, blocked with $5 \%$ nonfat dry milk in Trisbuffered saline containing $0.1 \%$ Tween-20 (TBST) for $1 \mathrm{~h}$ at room temperature. The membranes were incubated for $2 \mathrm{~h}$ at room temperature with antibody. Equal lane loading was assessed using $\beta$-actin monoclonal antibody (Sigma). After washing with TBST, blots were incubated with 1:5,000 dilution of the horseradish peroxidase conjugated-secondary antibody (Zymed, San Francisco, CA, USA), and washed again three times with TBST. The transferred proteins were visualized with an enhanced chemiluminescence detection kit (Amersham Pharmacia Biotech, Buckinghamshire, UK).

\section{Immunoprecipitation}

Two hundred micrograms of the cell lysates were mixed with $1 \mu \mathrm{g}$ of antibody and incubated overnight at $4{ }^{\circ} \mathrm{C}$ with constant rotation. To recover immunoprecipitated complexes, $150 \mu \mathrm{l}$ of protein A-sepharose, diluted 1:1 in PBS, were then added to the samples and incubated on ice for an additional two to four hours with constant rotation. The beads were pelleted by centrifugation and the bound proteins were eluted by incubation in $5 \mathrm{X}$ SDS loading buffer for five minutes by boiling. The eluted proteins were analyzed by immunoblot analysis.

\section{Chromatin immunoprecipitation (ChIP) assay}

Hep3B cells exposed to hypoxia as indicated in the figure legends were cross-linked by adding formaldehyde to a final concentration of $1 \%$ and incubating at $37^{\circ} \mathrm{C}$ for 10 minutes. Cells were washed twice with ice-cold phosphate-buffered saline. Cells were washed sequentially in Buffer 1 (0.25\% Triton X-100, 10 mM EDTA, $0.5 \mathrm{mM}$ EGTA, $10 \mathrm{mM}$ HEPES, pH 6.5) and Buffer 2 (200 mM NaCl, $1 \mathrm{mM}$ EDTA, $0.5 \mathrm{mM}$ EGTA, $10 \mathrm{mM}$ HEPES, pH 6.5). Cells were pelleted at $4^{\circ} \mathrm{C}$ and resuspended in $0.3 \mathrm{ml}$ of cell lysis buffer $(50 \mathrm{mM}$ Tris- $\mathrm{HCl}$ $\mathrm{pH} 8.1,10 \mathrm{mM}$ EDTA, 1\% SDS) containing complete protease inhibitor mixture (Sigma). Cell lysates were sonicated to yield DNA fragments ranging in size from 200 to $900 \mathrm{bp}$. Samples were centrifuged for 15 minutes at $4^{\circ} \mathrm{C}$. Supernatants were diluted 10 -fold to a final solution containing $20 \mathrm{mM}$ Tris- $\mathrm{HCl}(\mathrm{pH} \mathrm{8.1),} \mathrm{1 \%} \mathrm{Triton}$ $\mathrm{X}-100,2 \mathrm{mM}$ EDTA, $150 \mathrm{mM} \mathrm{NaCl}$, and complete protease inhibitor mixture. Eluates were then incubated with $2 \mu \mathrm{g}$ of HIF- $1 \alpha$ antibody (BD Biosciences) overnight at $4^{\circ} \mathrm{C}$ followed by the addition of $50 \mu \mathrm{l}$ of $50 \%$ slurry of protein A or protein G-Sepharose and incubated at $4^{\circ} \mathrm{C}$ for an additional two hours. Sepharose beads were pelleted and washed sequentially for $10 \mathrm{~min}$ utes each in TSE I (0.1\% SDS, 1\% Triton X-100, $2 \mathrm{mM}$ EDTA, $20 \mathrm{mM}$ Tris, $\mathrm{pH} 8.1,150 \mathrm{mM} \mathrm{NaCl}$ ), TSE II (0.1\% SDS, 1\% Triton X-100, 2 mM EDTA, $20 \mathrm{mM}$ Tris, pH 8.1, $500 \mathrm{mM} \mathrm{NaCl})$, and Buffer III (0.25 M $\mathrm{LiCl}, 1 \%$ Nonidet P-40, 1\% deoxycholate, $1 \mathrm{mM}$ EDTA, $10 \mathrm{mM}$ Tris, $\mathrm{pH}$ 8.1). Beads were washed another three times in Tris-EDTA, $\mathrm{pH}$ 8.0, and protein-DNA complexes were eluted in $300 \mu$ l of elution buffer (1\% SDS, $0.1 \mathrm{M} \mathrm{NaHCO} 3)$. Chemical cross-links were reversed by 
heating the samples overnight at $65^{\circ} \mathrm{C}$; the DNA was separated from protein and used as a template for PCR reactions. The yield of target region DNA in each sample after ChIP was analyzed by conventional PCR. The following primers were used for PCR analysis: VEGF promoter -1215 to -881 (HRE-containing region), forward 5'- TTGGGCTGATAGAAGCCTTG -3' and reverse 5' - TGGCACCAAGTTTGTGGAGC -3'. For qPCR, standard curves were generated by serially diluting an input chromatin sample. DNA regions were amplified using the following primers: VEGF promoter -1077 to -975 (HRE-containing region), forward 5'CCTCAGTTCCCTGGCAACATCTG-3' and reverse 5'GAAGAATTTGGCACCAAGTTTGT-3' [GenBank: AF095785.1].

\section{Statistical analysis}

Values shown represent the mean \pm SD. Statistical analysis was performed by Student's $t$-test, and a $P$-value $<0.05$ was considered significant.

\section{Results}

\section{ER $\beta$ decreases HIF- $1 \alpha$ mediated gene transcription}

We have previously reported that overexpression of ER $\beta$ suppresses hypoxia-induced endogenous VEGF mRNA [24]. To determine whether ER $\beta$ affects hypoxia-induced VEGF secretion, HEK293 cells were transfected with vector control or ER $\beta$ and exposed to hypoxia for $48 \mathrm{~h}$. VEGF secretion was measured by ELISA. As shown in Figure 1A, expression of ER $\beta$ significantly decreased VEGF secretion under hypoxic condition. To further characterize the molecular details of ER $\beta$ inhibition of hypoxia-induced transcription activation, we studied the effect of ER $\beta$ expression on HIF- $1 \alpha$-mediated gene transcription by using an HRE-driven reporter gene. HEK293 cells were transfected with an HRE-Luc plasmid with or without an expression vector for ER $\beta$ under hypoxia. As shown in Figure 1B, C, the HRE-driven luciferase reporter was markedly activated by hypoxia, whereas ER $\beta$ significantly inhibited this hypoxic activation in a dose dependent manner. Next, we examined whether the inhibition was dependent on HIF-1 $\alpha$ by using GFP-HIF-1 $\alpha$, which showed increased stability enough to carry out HIF-1 functional analyses under normoxia. The expression of ER $\beta$ significantly decreased the transcriptional activity of HIF- $1 \alpha$ under normoxia (Figure 1D). However, the E2 or ER antagonist, ICI, did not additionally affect this suppression (Figure 1D). This shows that unoccupied ER $\beta$ itself serves as a negative regulator of HIF-1.

\section{HIF-1 suppression by ER $\beta$ is due to ARNT degradation}

Association of HIF- $1 \alpha$ with ARNT, forming a heterodimeric complex, is required for it to bind to the HRE of target genes and its subsequent transactivation function [18]. As adequate levels of ARNT protein are required for the formation of the active HIF-1 heterodimeric complex, we determined the effect of ER $\beta$ on the expression of ARNT. To our surprise, we observed that ER $\beta$ down-regulates the ARNT protein levels in Hep3B and MCF-7 cells transfected with ER $\beta$ (Figure 2A). In addition, ARNT overexpression effectively rescued HIF1 repression by ER $\beta$ (Figure 2B). These results imply that ER $\beta$ induced HIF-1 transrepression is attributed to the down-regulation of ARNT. The involvement of ER $\beta$ modulation of ARNT protein level was also confirmed after knockdown of ER $\beta$ using RNA interference. As shown, ARNT protein levels were increased when the expression of ER $\beta$ was repressed in PC3 cells. Knockdown of ER $\beta$ mRNA by ER $\beta$-siRNA were validated by qPCR (Figure 3A). ER $\beta$ expression in cell lines used in this study is shown in Supplementary Figure S1 in Additional file 1 .

To further confirm the decrease in ARNT expression by $E R \beta$, we have examined suppression of AhR activity which exerts its effect by formation of heterodimer with ARNT. Dioxin-occupied AhR/ANRT complex is well known to induce CYP1A1 [25]. As shown, ER $\beta$ expression significantly suppressed dioxin induced CYP1A1 expression in MCF-7 cells (Figure 3B). The same effects were observed in rat hepatocytes (Supplementary Figure S2 in Additional file 2).

\section{Effects of ER $\beta$ on ARNT binding with HIF-1 $\alpha$}

Our data strongly suggest that ER $\beta$ decreases HIF- $1 \alpha$ mediated gene transcription through ARNT down-regulation. To further examine the functional consequences resulting from the degradation of ARNT protein, the formation of HIF-1 $\alpha /$ ARNT complexes was assessed in HEK293 cells. As shown in Figure 4, GFP-HIF-1 $\alpha$ / ARNT complex levels were significantly decreased by the overexpression of ER $\beta$ under normoxia, as determined by coimmunoprecipitation. In addition, ARNT overexpression effectively recovered HIF- $1 \alpha$ binding to ARNT (Figure 4), showing that ARNT degradation by ER $\beta$ is followed by the reduction of HIF-1 $\alpha / A R N T$ complex formation. In Figure 4, we detected no ARNT protein upon ER $\beta$ expression in contrast to the low levels of ARNT protein in Figure 2A. The difference in levels of ARNT protein between Figures $2 \mathrm{~A}$ and 4 is probably due to the efficiency of technique used in detection.

\section{ER $\beta$ degrades ARNT via the ubiquitin proteasome system}

The ubiquitin-proteasome pathway is responsible for many regulatory proteins. To examine the involvement of the proteasomal pathway in ER $\beta$-induced degradation of ARNT, HEK293 cells were transfected with ER $\beta$ and 


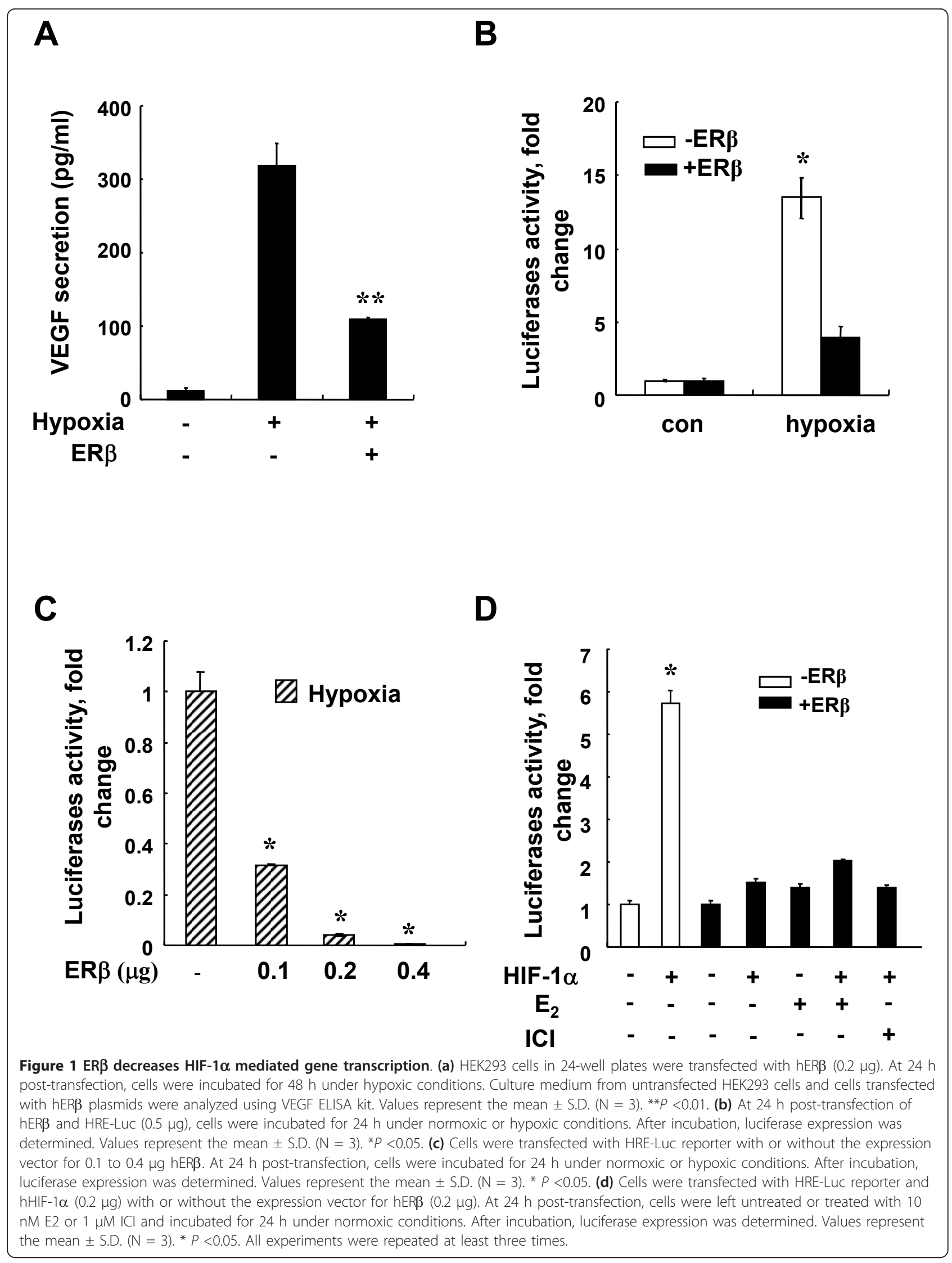




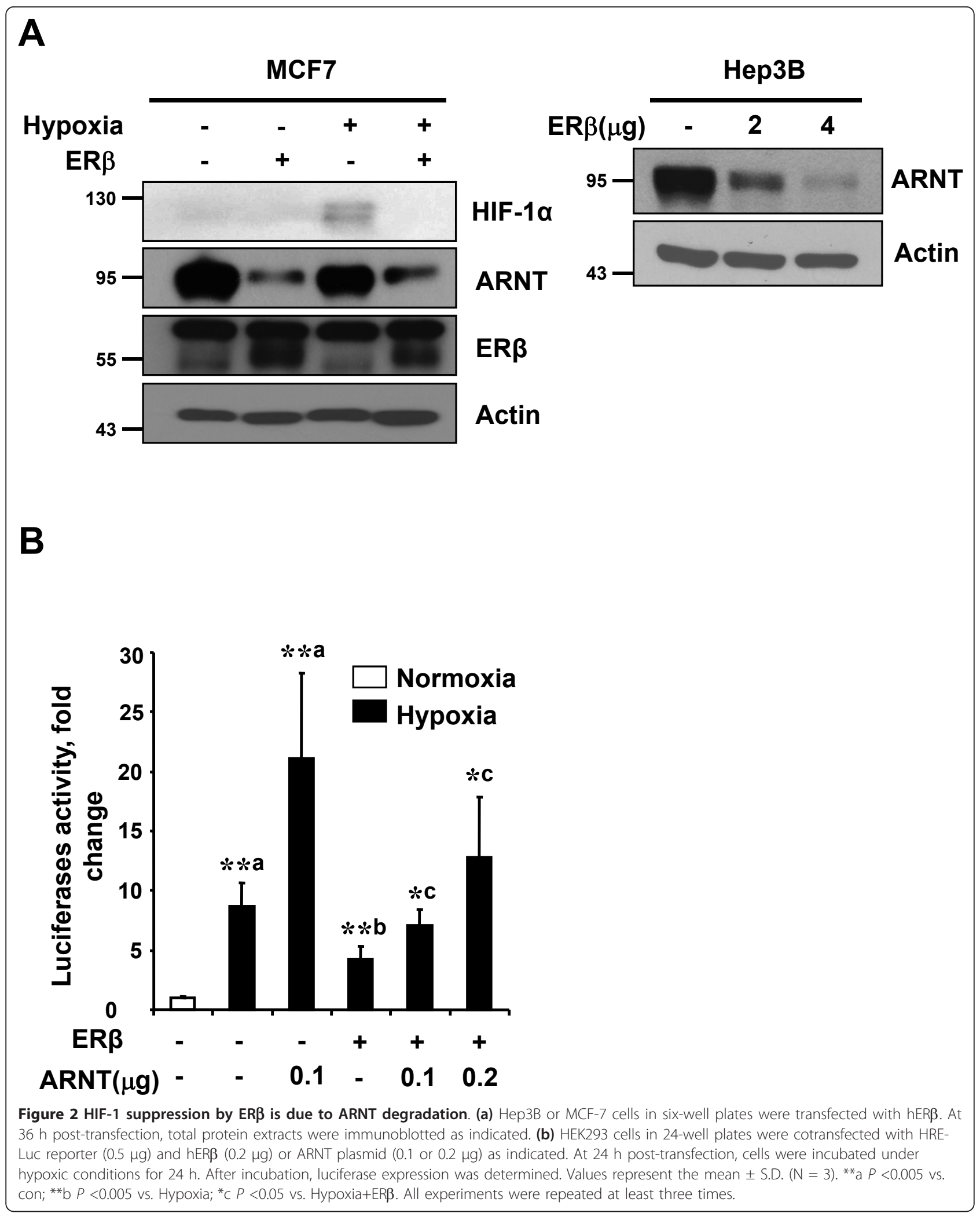




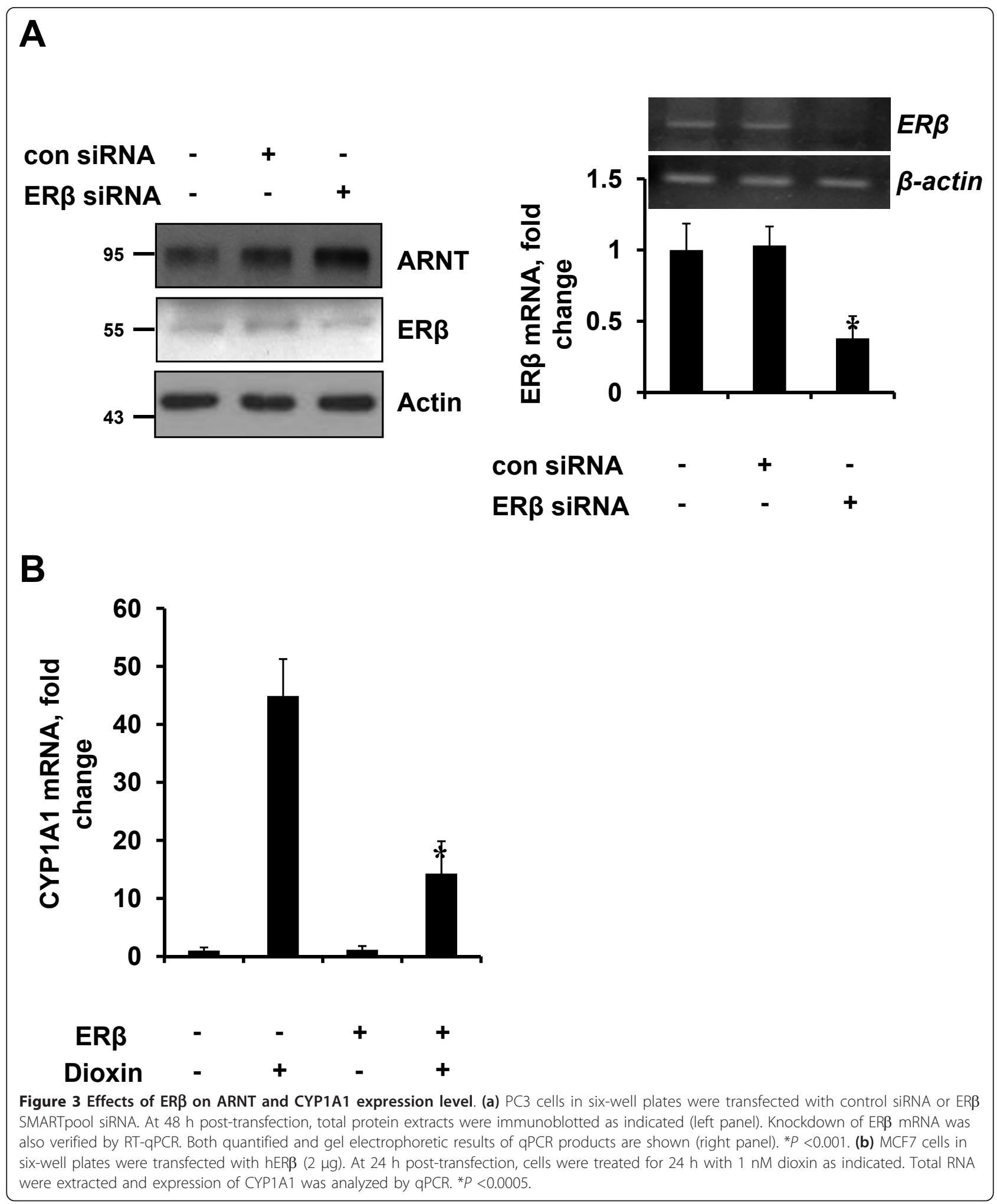




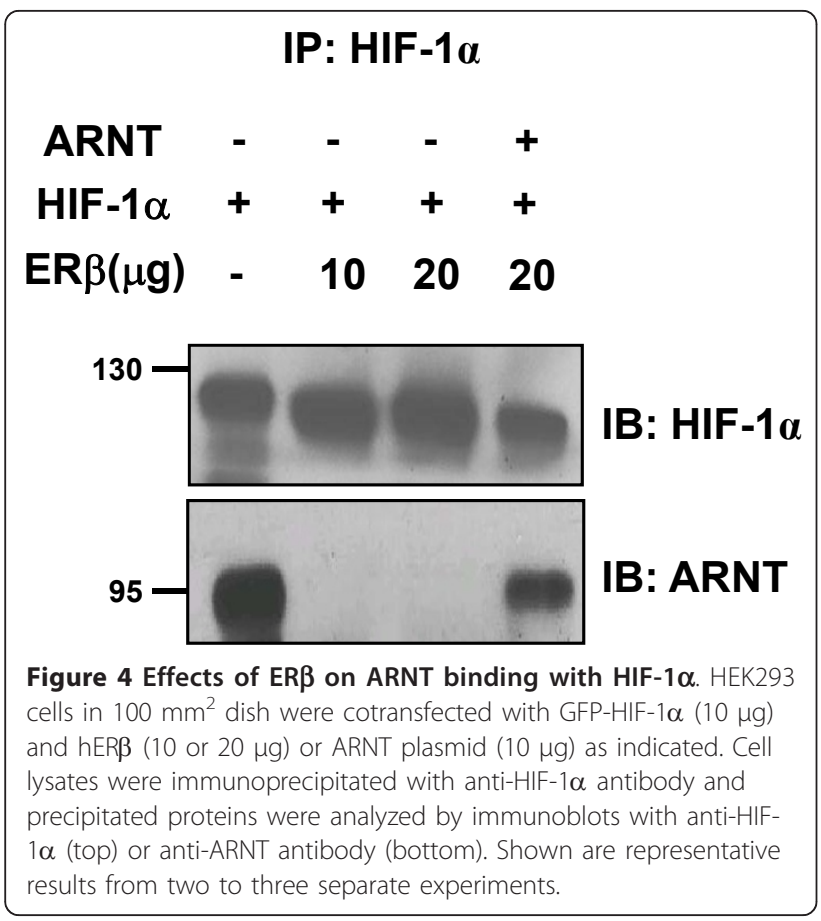

treated with or without $10 \mu \mathrm{M}$ of the proteasome inhibitor, MG132 for $12 \mathrm{~h}$. We analyzed the lysates using Western blots. As shown in Figure 5A, MG132 significantly blocked ARNT degradation by ER $\beta$, suggesting that ER $\beta$ degrades ARNT via the proteasomal pathway. Protein ubiquitination is a signal for targeted recognition and proteolysis by proteasome [26]. To assess ubiquitination of ARNT by ER $\beta$, cell lysates from HEK 293 cells transfected with ER $\beta$, ARNT, and His-Ubi were immunoprecipitated with anti-ARNT antibody and then analyzed by Western blot using anti-ubiquitin antibodies. As shown in Figure 5B, ubiqutination of the ARNT protein was enhanced by ER $\beta$ expression, indicating that this process is mediated through the ubiquitin-proteasome pathway.

ER $\beta$ decreases the hypoxic induction of VEGF by reducing the recruitment of HIF-1 to the hypoxia-dependent VEGF promoter

We have previously reported that ER $\beta$ decreases VEGF mRNA in HEK293 cells [24]. To examine the possibility that ER $\beta$ modulates the expression of VEGF in other cells, Hep3B cells were transfected with the expression vector for ER $\beta$ and exposed to hypoxia. The hypoxic induction of VEGF mRNA was significantly blocked by the overexpression of ER $\beta$ in Hep3B cells (Figure 6A).

HIF functions by binding to the HREs present in the promoter of hypoxic genes [27]. To investigate whether ER $\beta$ results in reduced HIF-1 recruitment to the VEGF promoter, we performed ChIP assays on the VEGF promoter in Hep3B cells. As shown in Figure 5B, association of HIF- $1 \alpha$ at the VEGF promoter after ER $\beta$ overexpression was significantly decreased compared with that in hypoxia-treated cells (Figure 6B). This shows that ER $\beta$ induced the down-regulation of the HIF-1 target gene expression resulting from a reduction in the level of HIF1 binding to the VEGF promoter.

\section{Discussion}

In this study, we sought to determine whether ER $\beta$ regulates HIF- $1 \alpha$-mediated transcription by targeting ARNT. Using a reporter-based assay, we found that ER $\beta$ decreased HIF-1 $\alpha$-mediated transcription. Hypoxic induction of endogenous VEGF was blocked by ER $\beta$ expression. This repression is due to ER $\beta$-induced down-regulation of ARNT via ubiquitination processes. Overexpression of ARNT rescued HIF-1 repression by ER $\beta$. Two important aspects of our study are that it provides a mechanistic explanation for ER $\beta$ as a tumour suppressor and a distinct function for unliganded ER $\beta$ in post-translational regulation. The tumour-suppressive role of ER $\beta$ in cancer biology currently is being widely studied [8]. ER $\beta$ inhibits angiogenesis and growth of T47D breast cancer xenografts [9]. Coradini et al. reported that VEGF synthesis under hypoxia was reduced in ER $\beta$-expressing MDA-MB231 breast cancer cells in contrast to MCF-7 cells containing both the $E R \alpha$ and ER $\beta$ isoforms [28]. A very recent study by Maik et al. showed that ligand-bound ER $\beta$ impedes prostate cancer epithelial-mesenchymal transition by destabilizing HIF- $1 \alpha$ and impeding HIF- 1 mediated transcription of VEGF [29]. Our data showed that ER $\beta$ suppresses HIF-1 activity and inhibits angiogenesis related gene expression by targeting ARNT. The detailed complex regulatory mechanisms of ER $\beta$ targeting HIF-1 components to proteasome need to be delineated.

ARNT plays a critical role in the transcriptional response to hypoxia and inactivation of ARNT is sufficient to suppress HIF target gene induction [30,31]. Reducing the cellular levels of ARNT significantly attenuated the transcriptional response of ER $\beta$ [2]. These results, along with our data, indicate that ER $\beta$-ARNT crosstalk is an important regulatory constituent responsible for the inhibitory effects of ER $\beta$ in hypoxia response, although the gap between ER $\beta$ and proteasomal degradation of ARNT still needs to be investigated. Pongratz group has reported the role of ARNT as a modulator of ERs. C-terminal part of ARNT interacts with the ER ligand binding domain [2]. Since ubiquitination by proteins such as carboxyl terminus of Hsc 70 interacting protein, a regulatory subunit of 26 S proteasome SUG1/TRIP1 and E6-AP ubiquitin ligase promotes ligand-induced degradation of ER $\beta$ [32], ER $\beta$-ARNT co-regulator complexes may contain proteins inducing ARNT degradation. Despite the 


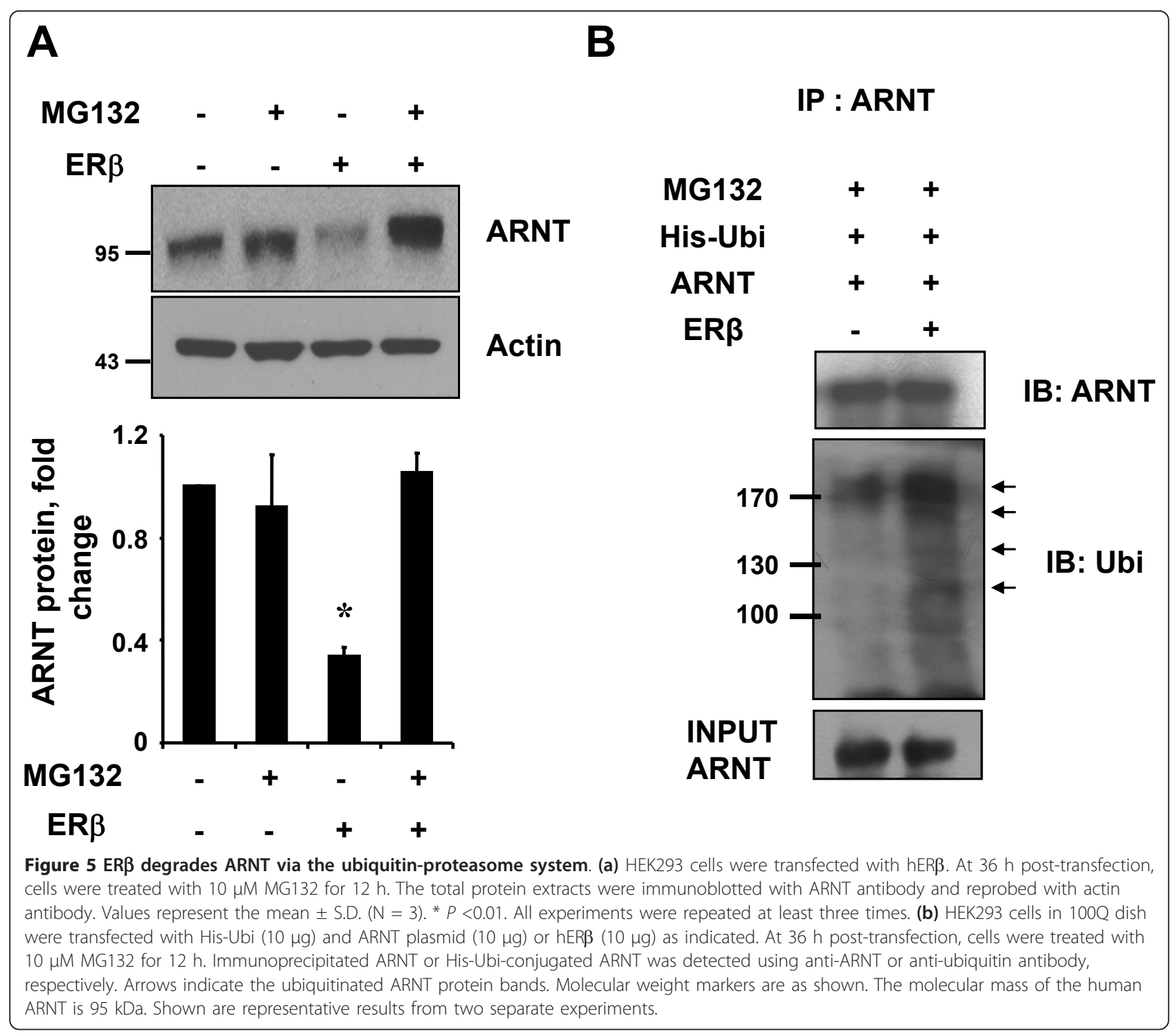

extensive study on HIF- $1 \alpha$ regulation, little is known about ARNT regulation. ARNT is present at constituent levels with a short half life of $4.84 \mathrm{~h}$. There are other tumour inhibitory substances targeting ARNT degradation such as curcumin, a major component of turmeric [33]. Curcumin induces degradation of ARNT via oxidation and ubiquitination. Further work will reveal the identity of protein complexes responsible for ARNT degradation.

The modulation of hypoxic transcription is not confined to the ER $\beta$. Nuclear hormone receptors affecting hypoxic activity are reported by several groups [34-39]. E2 protects against hypoxic/ischemic white matter damage in the neonatal rat brain [40] and hypoxiainduced hepatocyte injury through ER-mediated upregulation of Bcl-2 [41]. Hypoxia either enhances or inhibits transcriptional activity of glucocorticoid receptors [42], androgen receptors [43], ERs [24,44-47], and peroxisome proliferator-activated receptors [48-51] depending on the experimental systems. Increased glucocorticoid sensitivity after hypoxia exposure has been observed [52], suggesting that hypoxia may influence the inflammation process as well. Despite the importance of understanding the crosstalk between nuclear receptors and hypoxia-responsive pathways, which will greatly aid the progress of cancer biology, the mechanism of the crosstalk is not yet understood. It is possible that common co-regulator(s) may be involved rather than specific co-regulators for each nuclear hormone receptor in hypoxia and nuclear receptor crosstalk. HIF-1 transactivates and down-regulates ER $\alpha[45,46]$, so the co-regulator(s) may contain proteasome activity. Recent reports 


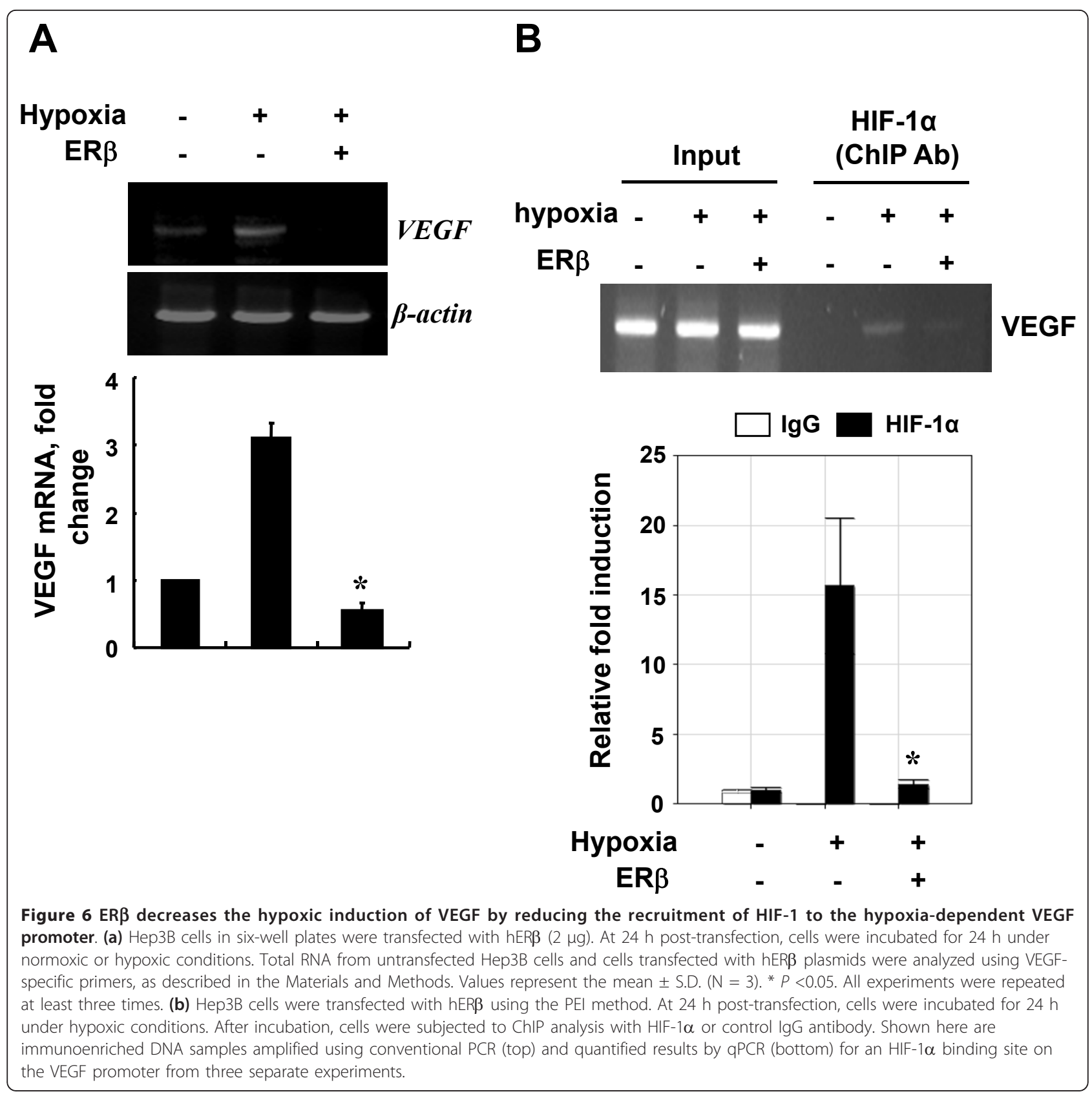

showed that the carboxy terminus of $70-\mathrm{kDa}$ heat shock protein-interacting protein, which can degrade ER $\alpha$, contains a dual function as an ubiqutin ligase and tumour suppressor [53].

Another interesting aspect of our result is that the effect of ER $\beta$ on hypoxia-mediated response is independent of ligand. Unoccupied ER $\alpha$ is known to be associated with DNA, even before ligand exposure. ChIP data showed that unliganded ER $\alpha$ is assembled with transcription activation complexes for tumour necrosis factor- $\alpha$ induction [54]. Maynadier et al. reported that unliganded ER $\alpha$ inhibits cell growth through interaction with the cyclin-dependent kinase inhibitor p21WAF1 [55]. Lazennec et al. showed that overexpression of ER $\beta$ inhibited E2 induced cell proliferation even at low E2 concentration [56] indicating that the effect of is not dependent on ligand. We and others have reported increased recruitment of SRC- 1 and CBP to ER $\beta$ by liganded independent manner by EGF, oncogene ras and hypoxia $[24,57,58]$. We envision that unliganded ER $\beta$ recruits protein complex containing proteasomal degradation function although we cannot completely preclude the possibility that in vitro overexpression system have aberrantly activated ER $\beta$. 


\section{Conclusions}

In conclusion, our study demonstrated that ER $\beta$ degrades ARNT via the ubiquitin-proteasome system leading to HIF-1 suppression. The ER $\beta / \mathrm{HIF}-1 \alpha / \mathrm{ARNT}$ pathway may play an important role in cancer progression. These findings suggest that HIF-1 suppression by ER $\beta$ may represent a potential therapeutic target in treating patients with ER-associated cancer.

\section{Additional material}

Additional file 1: Supplemental Figure S1. Expression level of ER $\beta$ in the following cells. MCF7, Hep3B and PC3 cells total protein extracts were immunoblotted with ARNT, ER $\beta$ and $\beta$-actin antibody.

Additional file 2: Supplemental Figure S2. Effects of ERß expression on CYP1A1 level. Hepa1c1c7 cells in six-well plates were transfected with hER $(2 \mu \mathrm{g})$ or same amounts of empty vector. At $24 \mathrm{~h}$ post-transfection, cells were treated for $48 \mathrm{~h}$ with $1 \mathrm{nM}$ dioxin as indicated. Total protein extractes were immunoblotted with ARNT and ERß (left panel). Total RNA were extracted and expression of CYP1A1 was analyzed by GRT-PCR (right panel). The expression level of $18 \mathrm{~S}$ rRNA was used for normalization. The primers used were: mouse Cyp1A1, 5'-

TTCCTGTCCTCCGTTACCTG-3' and 5'-CCTGTCCTGACAATGCTCAA-3'; 185 rRNA, 5'-ACCGCAGCTAGGAATAATGGAATA-3'; 5'-

CTTCGCTCTGGTCCGTCTT-3.

\section{Abbreviations}

ARNT: aryl hydrocarbon receptor nuclear translocator; ER: estrogen receptor; HIF: hypoxia-inducible factor; HRE: hypoxia-responsive element; RT-PCR: reverse transcription polymerase chain reaction; TCDD: 2,3,7,8tetrachlorodibenzo-p-dioxin; VEGF: vascular endothelial growth factor.

\section{Acknowledgements}

This work was supported by grants from the Korea Science and Engineering Foundation (KOSEF) grant funded by the Korea government (MEST) (20090064451; 2009-0071411; 2009-0084887), Technology Development Program for Agriculture and Forestry, Ministry for Agriculture, Forestry and Fisheries, Republic of Korea (109127-03-1-HD110) and BK21 to YJL and by a grant from the National R\&D Program for Cancer Control, Ministry for Health, Welfare and Family affairs, Republic of Korea (0920150) to HP.

\section{Author details}

'Department of Bioscience and Biotechnology, College of Life Science, Institute of Biotechnology, Sejong University, Kwangjingu, Kunjadong, Seoul 143-747, Korea. ${ }^{2}$ Department of Life Science, University of Seoul, Dongdaemungu, Jeonnong-dong, Seoul 130-743, Korea.

\section{Authors' contributions}

$W L, Y P, J C, J P, C P, Y P$ and HP carried out experiments and drafted the manuscript. YJL conceived of the study, participated in its design, coordination and interpretation of the results, and finalized the manuscript. All authors read and approved the final manuscript.

\section{Competing interests}

The authors declare that they have no competing interests.

Received: 22 June 2010 Revised: 12 December 2010 Accepted: 24 March 2011 Published: 24 March 2011

\section{References}

1. Hou YF, Yuan ST, Li HC, Wu J, Lu JS, Liu G, Lu LJ, Shen ZZ, Ding J, Shao ZM: ERbeta exerts multiple stimulative effects on human breast carcinoma cells. Oncogene 2004, 23:5799-5806.
2. Rüegg J, Swedenborg E, Wahlström D, Escande A, Balaguer P, Pettersson K, Pongratz I: The transcription factor aryl hydrocarbon receptor nuclear translocator functions as an estrogen receptor beta-selective coactivator, and its recruitment to alternative pathways mediates antiestrogenic effects of dioxin. Mol Endocrinol 2008, 22:304-316.

3. Ali $\mathrm{S}$, Coombes RC: Endocrine-responsive breast cancer and strategies for combating resistance. Nat Rev Cancer 2002, 2:101-112.

4. Fujita T, Kobayashi $Y$, Wada O, Tateishi Y, Kitada L, Yamamoto $Y$, Takashima H, Murayama A, Yano T, Baba T, Kato S, Kawabe Y, Yanagisawa J: Full activation of estrogen receptor alpha activation function-1 induces proliferation of breast cancer cells. J Biol Chem 2003, 278:26704-26714.

5. Helguero LA, Faulds MH, Gustafsson JA, Haldosén LA: Estrogen receptors alpha (ERalpha) and beta (ERbeta) differentially regulate proliferation and apoptosis of the normal murine mammary epithelial cell line HC11. Oncogene 2005, 24:6605-6616.

6. Ström A, Hartman J, Foster JS, Kietz S, Wimalasena J, Gustafsson JA: Estrogen receptor beta inhibits 17 beta-estradiol-stimulated proliferation of the breast cancer cell line T47D. Proc Natl Acad Sci U S A 2006, 101:1566-1571.

7. Paruthiyil S, Parmar H, Kerekatte V, Cunha GR, Firestone GL, Leitman DC: Estrogen receptor beta inhibits human breast cancer cell proliferation and tumor formation by causing a G2 cell cycle arrest. Cancer Res 2004, 64:423-428.

8. Sotoca AM, van den Berg $H$, Vervoort J, van der Saag P, Ström A, Gustafsson JA, Rietjens I, Murk AJ: Influence of cellular ERalpha/ERbeta ratio on the ERalpha-agonist induced proliferation of human T47D breast cancer cells. Toxicol Sci 2008, 105:303-311.

9. Hartman J, Lindberg K, Morani A, Inzunza J, Ström A, Gustafsson JA: Estrogen receptor beta inhibits angiogenesis and growth of T47D breast cancer xenografts. Cancer Res 2006, 66:11207-11213.

10. Hartman J, Edvardsson K, Lindberg K, Zhao C, Williams C, Ström A, Gustafsson JA: Tumor repressive functions of estrogen receptor beta in SW480 colon cancer cells. Cancer Res 2009, 69:6100-6106.

11. Zhao C, Dahlman-Wright K, Gustafsson JA: Estrogen receptor beta: an overview and update. Nucl Recept Signal 2008, 6:e003.

12. Zheng $X$, Linke $S$, Dias JM, Zheng $X$, Gradin $K$, Wallis TP, Hamilton BR, Gustafsson M, Ruas JL, Wilkins S, Bilton RL, Brismar K, Whitelaw ML, Pereira T, Gorman JJ, Ericson J, Peet DJ, Lendahl U, Poellinger L: Interaction with factor inhibiting HIF-1 defines an additional mode of crosscoupling between the Notch and hypoxia signaling pathways. Proc Nat Acad Sci USA 2008, 105:3368-3373.

13. Harris AL: Hypoxia-a key regulatory factor in tumour growth. Nat Rev Cancer 2002, 2:38-47.

14. Semenza GL: Targeting HIF-1 for cancer therapy. Nat Rev Cancer 2003, 3:721-732

15. Gordan JD, Simon MC: Hypoxia-inducible factors: central regulators of the tumor phenotype. Curr Opin Genet Dev 2007, 17:71-77.

16. Tam BY, Wei K, Rudge JS, Hoffman J, Holash J, Park SK, Yuan J, Hefner C, Chartier C, Lee JS, Jiang S, Niyak NR, Kuypers FA, Ma L, Sundram U, Wu G, Garcia JA, Schrier SL, Maher JJ, Johnson RS, Yancopoulos GD, Mulligan RC, Kuo CJ: VEGF modulates erythropoiesis through regulation of adult hepatic erythropoietin synthesis. Nat Med 2006, 12:793-800.

17. Yoon D, Pastore YD, Divoky V, Liu E, Mlodnicka AE, Rainey K, Ponka P, Semenza GL, Schumacher A, Prchal JT: Hypoxia-inducible factor-1 deficiency results in dysregulated erythropoiesis signaling and iron homeostasis in mouse development. J Biol Chem 2006, 281:25703-25711.

18. Grimm C, Wenzel A, Groszer M, Mayser H, Seeliger M, Samardzija M, Bauer C, Gassmann M, Remé CE: HIF-1-induced erythropoietin in the hypoxic retina protects against light-induced retinal degeneration. Nat Med 2002, 8:718-724.

19. Kallio PJ, Okamoto K, O'Brien S, Carrero P, Makino Y, Tanaka H, Poellinger L: Signal transduction in hypoxic cells: inducible nuclear translocation and recruitment of the CBP/p300 coactivator by the hypoxia-inducible factor-1alpha. EMBO J 1998, 17:6573-6586.

20. Kallio PJ, Pongratz I, Gradin K, McGuire J, Poellinger L: Activation of hypoxia-inducible factor 1alpha: posttranscriptional regulation and conformational change by recruitment of the Arnt transcription factor. Proc Natl Acad Sci USA 1997, 94:5667-5672.

21. Brunnberg S, Pettersson K, Rydin E, Matthews J, Hanberg A, Pongratz I: The basic helix-loop-helix-PAS protein ARNT functions as a potent 
coactivator of estrogen receptor-dependent transcription. Proc Natl Acad Sci USA 2003, 100:6517-6522.

22. Kronenberg S, Esser C, Carlberg C: An aryl hydrocarbon receptor conformation acts as the functional core of nuclear dioxin signaling. Nucleic Acids Res 2000, 28:2286-2291.

23. Jensen KA, LuU TC, Chan WK: A truncated Ah receptor blocks the hypoxia and estrogen receptor signaling pathways: a viable approach for breast cancer treatment. Mol Pharm 2006, 3:695-703.

24. Lim W, Cho J, Kwon HY, Park Y, Rhyu MR, Lee Y: Hypoxia-inducible factor 1 alpha activates and is inhibited by unoccupied estrogen receptor beta. FEBS Lett 2009, 583:1314-1318.

25. Mimura J, Fujii-Kuriyama Y: Functional role of AhR in the expression of toxic effects by TCDD. Biochim Biophys Acta 2003, 1619:263-268.

26. Murata T, Shimotohno K: Ubiquitination and proteasome-dependent degradation of human eukaryotic translation initiation factor $4 \mathrm{E}$. J Biol Chem 2006, 281:20788-20800.

27. Wenger RH, Stiehl DP, Camenisch G: Integration of oxygen signaling at the consensus HRE. SCi STKE 2005, 2005:re12.

28. Coradini D, Pellizzaro C, Speranza A, Daidone MG: Hypoxia and estrogen receptor profile influence the responsiveness of human breast cancer cells to estradiol and antiestrogens. Cell Mol Life Sci 2004, 61:76-82.

29. Mak P, Leav I, Pursell B, Bae D, Yang X, Taglienti CA, Gouvin LM, Sharma VM, Mercurio AM: ERbeta impedes prostate cancer EMT by destabilizing HIF-1alpha and inhibiting VEGF-mediated snail nuclear localization: implications for Gleason grading. Cancer Cell 2010, 17:319-332.

30. Maltepe E, Schmidt JV, Baunoch D, Bradfield CA, Simon MC: Abnormal angiogenesis and responses to glucose and oxygen deprivation in mice lacking the protein ARNT. Nature 1997, 386:403-407.

31. Rankin EB, Higgins DF, Walisser JA, Johnson RS, Bradfield CA, Haase VH: Inactivation of the arylhydrocarbon receptor nuclear translocator (Arnt) suppresses von Hippel-Lindau disease-associated vascular tumours in mice. Mol Cell Biol 2005, 25:3163-3172.

32. Tateishi $Y$, Sonoo R, Sekiya $Y$, Sunahara N, Kawano M, Wayama M, Hirota $R$, Kawabe Y, Murayama A, Kato S, Kimura K, Yanagisawa J: Turning off estrogen receptor beta-mediated transcription requires estrogendependent receptor proteolysis. Mol Cell Biol 2006, 26:7966-7976.

33. Choi H, Chun YS, Kim SW, Kim MS, Park JW: Curcumin inhibits hypoxiainducible factor-1 by degrading aryl hydrocarbon receptor nuclear translocator: a mechanism of tumor growth inhibition. Mol Pharmacol 2006, 70:1664-1671.

34. Mukundan H, Kanagy NL, Resta TC: 17-beta estradiol attenuates hypoxic induction of HIF-1alpha and erythropoietin in Hep3B cells. J Cardiovasc Pharmacol 2004, 44:93-100.

35. Earley S, Resta TC: Estradiol attenuates hypoxia-induced pulmonary endothelin-1 gene expression. Am J Physiol Lung Cell Mol Physiol 2002, 283:L86-L93.

36. Crossno JT Jr, Garat CV, Reusch JE, Morris KG, Dempsey EC, McMurtry IF, Stenmark KR, Klemm DJ: Rosiglitazone attenuates hypoxia-induced pulmonary arterial remodeling. Am J Physiol Lung Cell Mol Physiol 2007, 292:L885-L897.

37. Lee KS, Kim SR, Park SJ, Park HS, Min KH, Jin SM, Lee MK, Kim UH, Lee YC: Peroxisome proliferator activated receptor-gamma modulates reactive oxygen species generation and activation of nuclear factor-kappaB and hypoxia-inducible factor 1alpha in allergic airway disease of mice. J Allergy Clin Immunol 2006, 118:120-127.

38. Wagner AE, Huck G, Stiehl DP, Jelkmann W, Hellwig-Bürgel T: Dexamethasone impairs hypoxia-inducible factor-1 function. Biochem Biophys Res Commun 2008, 372:336-340.

39. Sandau US, Handa RJ: Glucocorticoids exacerbate hypoxia-induced expression of the pro-apoptotic gene Bnip3 in the developing cortex. Neuroscience 2007, 144:482-494.

40. Gerstner B, Lee J, Desilva TM, Jensen FE, Volpe JJ, Rosenberg PA: 17betaestradiol protects against hypoxic/ischemic white matter damage in the neonatal rat brain. J Neurosci Res 2009, 87:2078-2086.

41. Lee MY, Lee JH, Han HJ: Estradiol-17beta protects against hypoxiainduced hepatocyte injury through ER-mediated upregulation of BCl-2 as well as ER-independent antioxidant effects. Cell Res 2008, 18:491-499.

42. Kodama T, Shimizu N, Yoshikawa N, Makino Y, Ouchida R, Okamoto K, Hisada T, Nakamura H, Morimoto C, Tanaka H: Role of the glucocorticoid receptor for regulation of hypoxia-dependent gene expression. $J$ Biol Chem 2003, 278:33384-33391.

43. Park SY, Kim YJ, Gao AC, Mohler JL, Onate SA, Hidalgo AA, Ip C, Park EM, Yoon SY, Park YM: Hypoxia increases androgen receptor activity in prostate cancer cells. Cancer Res 2006, 66:5121-5129.

44. Yi JM, Kwon HY, Cho JY, Lee YJ: Estrogen and hypoxia regulate estrogen receptor alpha in a synergistic manner. Biochem Biophys Res Commun 2009, 378:842-846.

45. Cho J, Kim D, Lee $S$, Lee Y: Cobalt chloride-induced estrogen receptor alpha down-regulation involves hypoxia-inducible factor-1alpha in MCF7 human breast cancer cells. Mol Endocrinol 2005, 19:1191-1199.

46. Cho J, Bahn JJ, Park M, Ahn W, Lee YJ: Hypoxic activation of unoccupied estrogen-receptor-alpha is mediated by hypoxia-inducible factor-1 alpha. J Steroid Biochem Mol Biol 2006, 100:18-23.

47. Stoner M, Saville B, Wormke M, Dean D, Burghardt R, Safe S: Hypoxia induces proteasome-dependent degradation of estrogen receptor alpha in ZR-75 breast cancer cells. Mol Endocrinol 2002, 16:2231-2242.

48. Belanger AJ, Luo Z, Vincent KA, Akita GY, Cheng SH, Gregory RJ, Jiang C: Hypoxia-inducible factor 1 mediates hypoxia-induced cardiomyocyte lipid accumulation by reducing the DNA binding activity of peroxisome proliferator-activated receptor alpha/retinoid X receptor. Biochem Biophys Res Commun 2007, 364:567-572.

49. Li X, Kimura H, Hirota K, Sugimoto H, Kimura N, Takahashi N, Fujii H, Yoshida $\mathrm{H}$ : Hypoxia reduces the expression and anti-inflammatory effects of peroxisome proliferator-activated receptor-gamma in human proximal renal tubular cells. Nephrol Dial Transplant 2007, 22:1041-1051.

50. Narravula S, Colgan SP: Hypoxia-inducible factor 1-mediated inhibition of peroxisome proliferator-activated receptor alpha expression during hypoxia. J Immunol 2001, 166:7543-7548.

51. Huss JM, Levy FH, Kelly DP: Hypoxia inhibits the peroxisome proliferatoractivated receptor alpha/retinoid $\mathrm{X}$ receptor gene regulatory pathway in cardiac myocytes: a mechanism for O2-dependent modulation of mitochondrial fatty acid oxidation. J Biol Chem 2001, 276:27605-27612.

52. Leonard MO, Godson C, Brady HR, Taylor CT: Potentiation of glucocorticoid activity in hypoxia through induction of the glucocorticoid receptor. J Immunol 2005, 174:2250-2257.

53. Fan M, Park A, Nephew KP: CHIP (carboxyl terminus of Hsc70-interacting protein) promotes basal and geldanamycin-induced degradation of estrogen receptor-alpha. Mol Endocrinol 2005, 19:2901-2914.

54. Cvoro A, Tzagarakis-Foster C, Tatomer D, Paruthiyil S, Fox MS, Leitman DC: Distinct roles of unliganded and liganded estrogen receptors in transcriptional repression. Mol Cell 2006, 21:555-564.

55. Maynadier M, Ramirez JM, Cathiard AM, Platet N, Gras D, Gleizes M, Sheikh MS, Nirde P, Garcia M: Unliganded estrogen receptor alpha inhibits breast cancer cell growth through interaction with a cyclindependent kinase inhibitor (p21(WAF1)). FASEB J 2008, 22:671-681.

56. Lazennec G, Bresson D, Lucas A, Chauveau C, Vignon F: ER beta inhibits proliferation and invasion of breast cancer cells. Endocrinology 2001, 142:4120-4130.

57. Tremblay A, Tremblay GB, Labrie F, Giguère V: Ligand-independent recruitment of SRC-1 to estrogen receptor beta through phosphorylation of activation function AF-1. Mol Cell 1999, 3:513-519.

58. Tremblay $A$, Giguère $V$ : Contribution of steroid receptor coactivator- 1 and CREB binding protein in ligand-independent activity of estrogen receptor beta. J Steroid Biochem Mol Biol 2001, 77:19-27.

doi:10.1186/bcr2854

Cite this article as: Lim et al.: Estrogen receptor beta inhibits transcriptional activity of hypoxia inducible factor-1 through the downregulation of arylhydrocarbon receptor nuclear translocator. Breast Cancer Research 2011 13:R32. 